\title{
CORRUPTION AND DECENTRALISATION: SOME EVIDENCE IN INDONESIA
}

\author{
Ferry Prasetyia \\ Fakultas Ekonomi Universitas Brawijaya
}

\begin{abstract}
This paper seeks to disentangle the relationship between decentralisation and corruption In Indonesia. The implementations of decentralisation in Indonesia in 2001, on one hand give an opportunity for local government for more responsive and accountable to citizens. Therefore, service delivery will improve and corruption will decline. On the other hand, more decentralisation has a positive impact on corruption, raising individual propensity to accept bribes due to an increasing an opportunities for corruption at local level. Some studies show that the implementation of decentralisation in Indonesia tends to an increasing in corruption at local level. However, some local governments have an initiative to addressing the problem of corruption through several approaches.
\end{abstract}

Keywords: Decentralisation, corruption, and local government.

\section{A. BACKGROUNDS}

The impact of governance decentralisation on corruption has been an interesting and debatable issue both in political and economics context. Decentralisation can be defined as an administrative change which gives lower levels of government greater administrative authority in delivering services (Kuncoro, 2006). In this sense, local governance is considered more responsive and accountable to citizens. The assumption is that localisation of authority, and decision-making being closer to the people would contribute to an increase in citizens' involvement in planning and budgeting. In addition, electoral accountability would be higher at the level of local government, as citizens are better informed about the performance of representatives and will decide on their continuance in the next term. All these are means by which the performance of elected representatives can be made accountable, and in ensuring transparency in public expenditure. Hence, it is assumed that service delivery will improve and corruption will decline.

Fisman and Gatti (2002) found that fiscal decentralisation in government expenditure is strongly and significantly associated with lower corruption. However, according to Carbonera (2000), it has been claimed that more decentralisation has a positive impact on corruption, raising individual propensity to accept bribes. It also argued (Prud'homme, 1995) that there are probably more opportunities for corruption at the local level: Firstly, local officials usually have more discretionary powers than national decision makers. Secondly, local bureaucrats and politicians are likely to be more subject to pressing demands from local interest groups in matters such as taxation.

Regarding decentralisation and corruption, Indonesia which is one of the developing countries in South East Asia that has implemented decentralisation in 2001 is the most corrupt country. One indication is the extent to which Indonesia is perceived to be a very corrupt country. Transparency International's 2007 Corruption Perception Index places Indonesia as 143 out of the 179 countries for which it compiled information, meaning that only 36 countries were perceived to be less corrupt. Compare to South East Asia countries, Indonesia is the most corrupt country in this region even if 
we compare to the former Indonesian province, Timor-Leste. Furthermore, according to study which is undertaken by Henderson and Kuncoro (2006) argued that corruption in Indonesia is widespread and costly.

Table 1. Transparency International Corruption Perceptions Index 2007

\begin{tabular}{clccc}
\hline $\begin{array}{c}\text { Country } \\
\text { Rank }\end{array}$ & Coun try & $\begin{array}{c}\mathbf{2 0 0 7} \text { CPI } \\
\text { Score }\end{array}$ & $\begin{array}{c}\text { Surveys } \\
\text { Used }\end{array}$ & Confidence Range \\
\hline 1 & Denmark & 9.4 & 6 & $9.2-9.6$ \\
1 & Finland & 9.4 & 6 & $9.2-9.6$ \\
1 & New Zealand & 9.4 & 6 & $9.2-9.6$ \\
4 & Singapore & 9.3 & 9 & $9.0-9.5$ \\
4 & Sweden & 9.3 & 6 & $9.1-9.4$ \\
6 & Iceland & 9.2 & 6 & $8.3-9.6$ \\
7 & Netherland & 9.0 & 6 & $8.8-9.2$ \\
7 & Switzerland & 9.0 & 6 & $8.8-9.2$ \\
9 & Canada & 8.7 & 6 & $8.3-9.1$ \\
9 & Norway & 8.7 & 6 & $8.0-9.2$ \\
11 & Australia & 8.6 & 8 & $8.1-9.0$ \\
43 & M alaysia & 5.1 & 9 & $4.5-5.7$ \\
84 & Thailand & 3.3 & 9 & $2.9-3.7$ \\
123 & Timor-Leste & 2.6 & 3 & $2.5-2.6$ \\
123 & Viet Nam & 2.6 & 9 & $2.4-2.9$ \\
131 & Philippines & 2.5 & 9 & $2.3-2.7$ \\
$\mathbf{1} \mathbf{4 3}$ & Ind on esia & $\mathbf{2 . 3}$ & $\mathbf{1 1}$ & $\mathbf{2 . 1}-\mathbf{2 . 4}$ \\
179 & Somalia & 1.4 & 4 & $1.1-1.7$ \\
\hline
\end{tabular}

Source: www.transparency.org

From the background research above, it can be clearly seen that decentralisation in Indonesia may give a high corruption opportunity. Thus, the objective of this research will concern the relationship between decentralisation and corruption in Indonesia; and gives some evidence about local government corruption.

\section{B. LITERATURE REVIEW}

\section{Overview of Corruption}

The word corruption has been used in many ways with differing connotations. In the economic context, however, it refers mainly to the use of public office for private gain (Shleifer and Vishny 1993). Some study (Mauro, 1995; world bank, 2003) states that corruption has been blamed for failures of certain developing countries to develop and there are positive links between higher perceived corruption and lower investment and growth.

One possibility causing corruption is related to the extensive government intervention (government policy) in the economy. The government intervention creates the rents that private parties must pay. When pervasive regulations exist and government official have an excessive degree of discretion in applying them, private parties may be willing to pay bribes to government in order to obtain any rents that the regulations may generate. Carbonera (2000) argued that there are three main causes of corruption in the public sphere as follows: (1) institutional incentives (e.g., discretion, complex procedures, patronage, low public wages); (2) lack of public information and transparency; and (3) lack of accountability of public officials. 


\section{Journal of Indonesian Applied Economics \\ Vol. 4 No. 1 Mei 2010, 34-42}

\section{The relationship between Decentralisation and Corruption}

From the theoretical framework, how decentralisation affects corruption is ambiguous. The first view suggests that decentralisation leads to greater fragmentation of government decision making power. The breakdown of coordination among bureaucrats may lead to excess rent extraction (Shleifer and Vishny,1993). Proponent with this argument, Treisman (2000) found that federalist country have higher rate of corruption due to the problem of "overgrazing" among different levels of government entities over the same targets.

In addition, Prud'home (1995) and Tanzi (1994) argued that the low capacity of local bureaucrats in delivering public goods and services may prevent the realization of benefits from decentralisation. Furthermore, Bardhan and Mookherjee (2000) states that interest groups may be more cohesive at the local level, leading to greater state capture and the substitution of private transfers for public services. If this theoretical argument is correct, countries in which a greater share of public business is conducted at sub-national levels would be more corrupt and less effective at providing public goods than those in which public services are more centralised.

The opposite view suggests that decentralisation is expected to have moderating impact on corruption, by increasing the role of the local government and accentuating the forces of interjurisdictional and political competition (Tiebout 1956 in Huther and Shah,1998; Fisman and Gatti, 2002). Jin et al (1999 in Kuncoro 2006) highlighted that competition among localities will discourage governments from adopting interventionist policies - fearing that mobile factors of productions may run away to less interventionist jurisdictions. There is however a more moderate stance that holds a view that whether decentralisation should encourage or discourage bureaucratic rent-seeking would depend on whether expenditure decentralisation is accompanied by the devolution of revenue generation to local governments or not (Smoke and Lewis, 1996).

Some studies review evidence from cross-country regressions concerning the relation between decentralisation and measures of corruption and government performance. Estache and Sinha (1995) researched this topic based on a panel dataset of 20 countries from 1970 to 1992. They evaluated the relation between a measure of expenditure decentralisation and per capita delivery of different forms of infrastructure. They found a significant positive association in general, an effect which was stronger when there was greater revenue decentralisation. In fact, there was little significant association when sub national governments relied almost exclusively on central grants. Hence they found a significant positive interaction between expenditure and revenue decentralisation in their effects on infrastructure delivery and negatively effect on corruption.

Similar result with the positive impact of decentralisation on governance is undertaken by Fisman and Gatti (2002) which examined the relation between the same measure of expenditure decentralisation and measures of corruption. They used dataset covers 59 countries for the period 1980 to 1995. The regression controls for an index of civil liberties, GDP, country size (population, government expenditure as a proportion of GDP), openness (import to GDP ratio), besides indices of ethnic fractionalization, contract enforceability, the existence of a federal constitution, regional and colonial dummies. They find a significant negative correlation between expenditure decentralisation and corruption measures, which is robust with respect to the precise set of controls or corruption measures or sub periods.

A contrasting picture emerges from a comprehensive set of cross-country regression results by Treisman (2000) who examines correlations between eight different measures of decentralisation with various measures of corruption and of social service delivery, while controlling for a larger range of variables. The same measure of expenditure decentralisation turns out to not have a significant association with corruption measures, despite using a similar set of countries and time period in the sample. Treisman (2000) explains the discrepancy from the Fisman-Gatti results by their use of a religion control variable: the proportion of Protestants in the population. This religion variable which was excluded by Fisman and Gatti turns out to account for the correlation they observed between corruption and expenditure decentralisation: countries with more Protestants tend to be both less corrupt and more decentralized. Expenditure decentralisation tends also to be 
positively correlated with youth illiteracy and negatively with access to sanitation, though positively correlated with paved roads. Hence, the use of a wider range of controls and of measures of governance quality tends to cast doubt on the earlier findings of Estache-Sinha and Fisman-Gatti (Treisman, 2000).

\section{RESEARCH METHODOLOGY AND DATA ANALYSIS}

\section{Research Approach}

This study used descriptive analysis which is used to obtain information concerning the current status of the phenomena to describe "what exists" with respect to conditions in a situation. In this case the situation is the implementation of fiscal decentralization in 2001 which have a high probability to an increasing in corruption opportunities, especially in local government.

\section{Method of Analysis}

This study used an exploratory research method. This kind of method trying to find and describe deeply about the relationships between decentralization and corruption in Indonesia. This method is very flexible in the search for new ideas and information, also can be a guidance on the conditions and circumstances relating to the issues that were examined in order to provide a clear picture, especially concerning fiscal decentralization and corruption especially case study in local government.

\section{RESEARCH FINDING AND ANALYSIS}

\section{Decentralisation and Corruption in Indonesia}

Indonesia is rapidly moving from a highly centralized system of government to a largely decentralized one after the fall of Soeharto's regime in 1998. The legal framework of decentralisation was enacted in 1999, and implemented starting 2001, devolves much of government service delivery to the regions, in particular, the now 416 local governments (districts and cities). It also sets out to increase political accountability of local governments. Regional governments now control about one third of total government spending, up from 17\% in 2000 (Kuncoro, 2005). Over time, the regions are likely to manage over half of government spending. Local governments are headed by region heads (bupatis or walikotas) who will ultimately all be elected by, and accountable to, regional parliaments (DPRDs). Decentralisation is bringing about a fundamental change in the organization and functioning of Indonesia's government.

The implementation of decentralisation in Indonesia base on the Law No. 22/1999 on Regional Government, replacing Law No.5/1974 on Government in the Regions, provided local government institutions with greater power, particularly relating to budget management and this, in turn, increased opportunities for corruption. According to Indonesian Corruption Watch research in 2006 about corruption in public institution shows that Pemda (local government) is the most corrupt institution with corrupt proportion at $40.71 \%$ followed by DPRD (regional parliaments), BUMD (local owned enterprises), and KPUD (regional election committee) at $20.71 \%, 20 \%$, and $6,43 \%$ respectively (figure 1). The least corrupt public institution are BKPM (capital management institution), Setneg (state secretary), Depkeu (department of finance) etc., with the proportion of corruption at $0.71 \%$. 


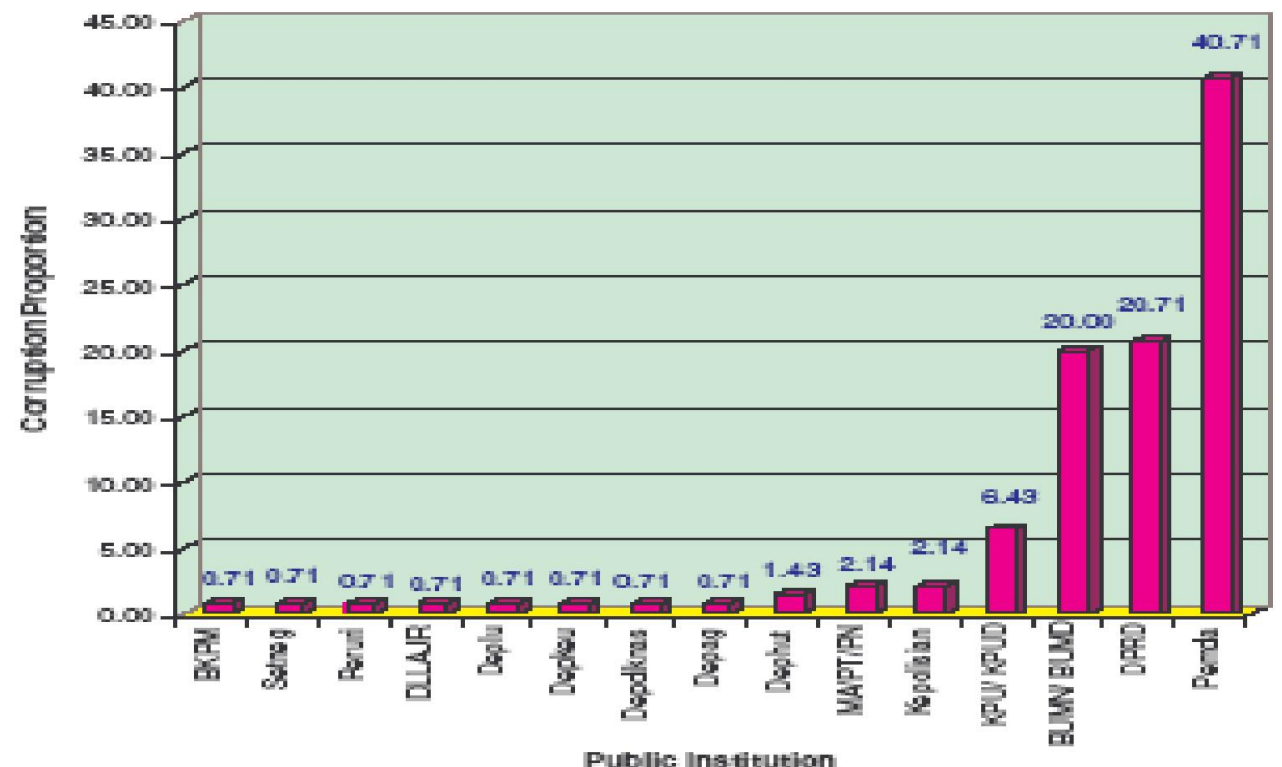

Figure 1. Corruption in Public Insttutions

Figure 1. reveals that the most corrupt institution is dominated by local public institution such as local government and local legislative (ICW, 2006). It can be clearly seen that the implementation of decentralisation give a great power for local government which leads to an increasing in corruption opportunities.

\section{Local Government and Corruption}

In other countries decentralisation may have no significant impact on corrupt behaviour, while In Indonesia is not the case. Corruption not just happened after the implementation of decentralisation in 2001 but already burdened with a severe corruption problem in the Soeharto era (Kuncoro, 2005). This means that decentralisation only makes the fragmentation of the bribe collection system much worse. In fact, there were some complaints from the Indonesian Chamber of Commerce (KADIN) on the rise of corruption at the local government level, immediately after the enactment of the Law of Decentralisation in 2001. It come from the fact that many new local regulations, especially on taxes, levies, and various type of permits, are designed to create artificial complementary regulations.

Kuncoro (2006) illustrated this condition with the example if in the past a business permit and a commercial driving licence were enough to ship goods from one district to another, a special pass is now needed from the district's revenue office because some goods are subject to taxation. A local government maximizes the revenue both from legal (taxation and levies) and illegal sources (bribery). However, high taxes and bribes tend to drive away firms from one locality. When this happens, corrupt officials lose potential incomes.

According to Rinaldi et al (2007) a year after regional autonomy entered into force in 2001, a wave of corruption cases swept across Indonesia's newly empowered regional parliaments. Rinaldi et al (2007) found in several regions such as West Sumatra in 2002, Central Sulawesi, West Kalimantan, Lampung, East Java there were some allegations of corruption emerge. An interesting example of corruption happened in 2002 which case of Local Budget Corruption in West Sumatra Provincial DPRD, 1999-2004 ( Legislative Provincial). The West Sumatra Provincial DPRD corruption case began at the initiative of several local NGOs and academics, which established the Care for West Sumatra Forum, (Forum Peduli Sumatera Barat-FPSB). FPSB regularly conducted reviews of Draft Local Budgets in FY 2002 and began uncovering corruption in the form of 27 
additional budget items relating to DPRD allowances and expenses amounting to IDR 5.9 billion. After warning the DPRD that it was in violation of PP 110/2000, the local anti-corruption actors began to agitate for legal proceedings on the allegation (ICW, 2006).

The other example of local budget corruption were in Blitar District Government ( Executive District). Blitar District Head and his staff manipulated the Local Budget FY 2002-2004 to show losses of IDR 97 billion. Exposure of this case came from an alliance of seven village heads, NGOs (Somasi and KRPK), and members of bureaucratic apparatus' Team-11. Although legal proceedings against the District Head and several staff members were successful, the Deputy District Head (currently the District Head) escaped punishment. The anti-corruption actors had support from a local private radio station that broadcasted the trial live. Further support came from the national level including the Attorney General's Office and the Supreme Court, which supervised the course of the legal proceedings at the local level.

More recently still, the trend has spreaded from regional legislatures into the executive. In 2006 , there were 265 corruption cases involving local legislative bodies with almost 1,000 suspects handled by prosecutorial offices across Indonesia. In the same year, the same offices had 46 corruption cases implicating 61 provincial Governors or District Heads (Rinaldi et al, 2007).

\section{Perception on Decentralisation and Corruption}

World bank (2003) undertook a survey about people perception on decentralisation and corruption in Indonesia (Figure 2). There is a widespread perception that there is considerable corruption in the regions. It appears to be systemic: money politics at the political level, corruption in core government operations such as recruitment, and government procurement, as well as petty corruption at the service delivery level are all seen as common.

Figure 2 reveals that people in the survey believed that money politics was involved in bupati election and accountability speech. Perception by Non Government Organisation (NGO) and media reveals that there were corruption/bribes by the government in form of tender of projects, compilation of local budget and official recruitment. People in the World Bank survey in 2003 also stated that the quality of services was decline due to corrupt behaviour and they conclude that corruption in decentralisation era is worse than before the implementation of decentralisation.

In order to combating corruption, national government has provide some legal framework such as: 1). Law 28/1999 on Clean Government Free from Corruption, Collusion and Nepotism, which, inter alia, defines corruption as a criminal act and requires public officials to report their wealth. 2). Law 31/1999 on Eradication of Criminal Acts of Corruption, which establishes tougher penalties for corruption - but continues to define corruption only as actions that cause losses to the stateand calls for the establishment of a Corruption Eradication Commission (KPK). 3). Law 20/2001 on Eradication of Criminal Acts of Corruption, which amends 31/1999 by expanding the definition of corruption and more clearly specifies acts of corruption.

In their survey, Davidsen et al (2006) shows that most observers feel that this body of laws provides an adequate legal basis for addressing corruption. More at issue is the willingness and ability of the various agencies of the government to fully and effectively implement these laws. However, in local level, many local governments have moved ahead with their own laws and regulations to improve governance and fight corruption; they are not looking to the national government for direction (Davidsen et al, 2006). The KPK has relationships with governments in a few kabupaten (districts) and provinces, but otherwise its influence outside of the national government still is limited.

There are some examples of local government initiatives to address corruption. In kabupaten solok: inspired by his participation in a ti workshop, in 2003 bupati gamawan fauzi, now the governor of west sumatra, required that all civil servants and suppliers sign an "integrity pact." The pact obliges them to refrain from corruption, not to receive or provide bribes, provide transparency to public and avoid in collusion/cronyism. The bupati has also reformed the rules for the procurement of goods and services in the kabupaten, simplifying documentation, reimbursement 


\section{Journal of Indonesian Applied Economics}

Vol. 4 No. 1 Mei 2010, 34-42

of funds, and correspondence in the procurement process.48 lastly, in early 2004, solok eliminated civil servants' honoraria, the salary supplements received by government staff for working on specific projects. The objective was to reduce corruption as well as improve employee welfare overall.

In line with Kabupaten Solok, city of Surabaya: in the response to presidential decree number 80/2003, in 2004 the newly elected walikota of Surabaya developed an e-procurement system for the city. To set up the system, the city government conducted its own research and tried to adopt the best practices of the procurement system in Hongkong and Singapore. It also received assistance setting up the computer system from students at the local school of engineering. Initially the government faced resistance from big vendors, who relied on payments and collusion to win their contracts. Since the implementation of the e-procurement system, the savings from procurements has been substantial, and the savings has been allocated to other city projects. In addition, the application of e-procurement increases the opportunity for small and medium vendors to participate in the bidding process. As a result, a big portion of the city's projects now are won by small and medium sized vendors

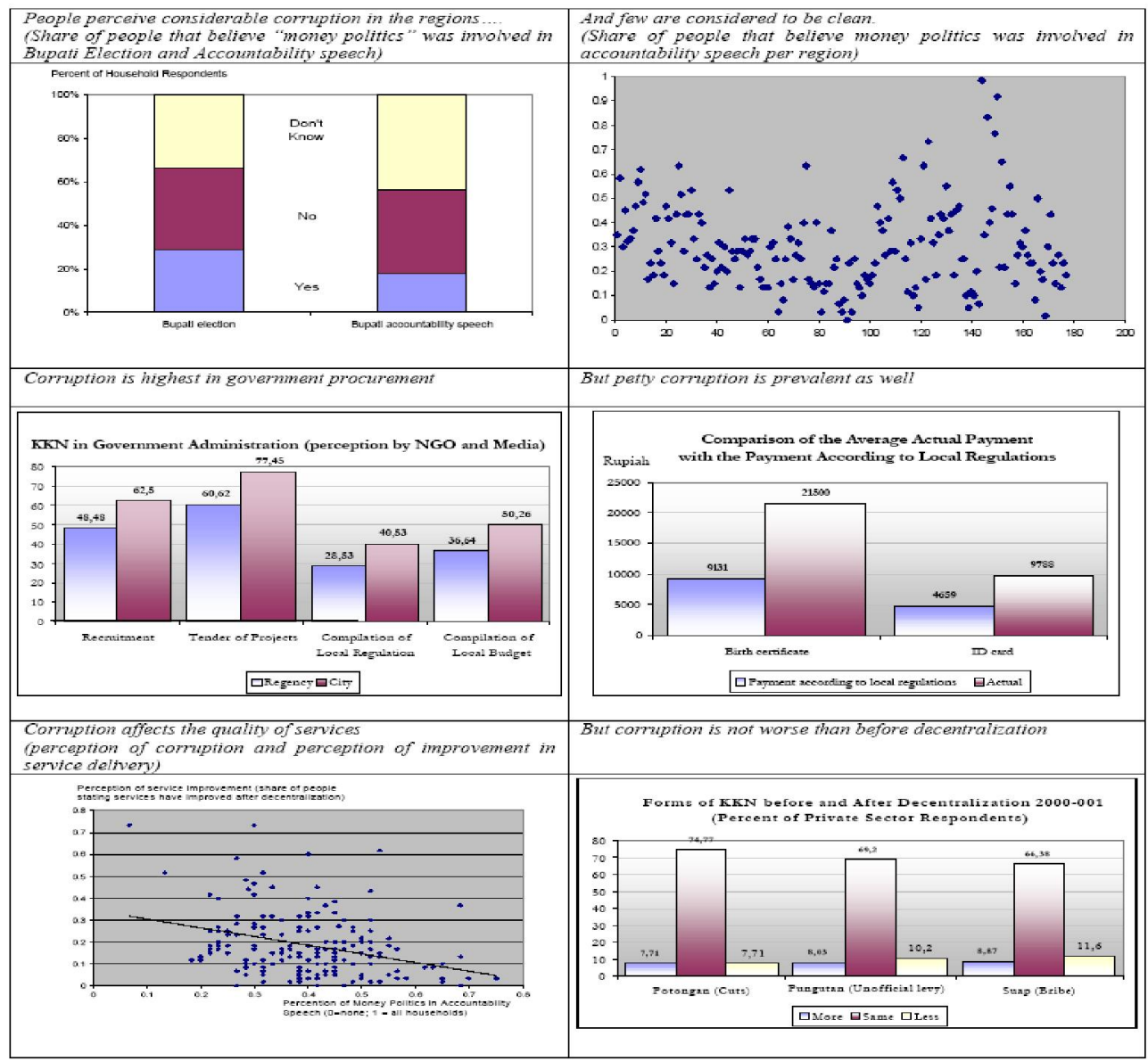

Source: World Bank (2003)

Figure 2. Perception on Decentralisation and Corruption in Indonesia

Olken (2005) gave three mechanisms for fighting local corruption in Indonesia. Firstly, topdown monitoring which is traditional economic approach to crime. National or local government monitor the corruption using their system. Secondly, bottom-up monitoring, for example community members have an important rule to combating corruption because local participants may have better information. However, Olsen mentioned that decentralized monitoring is a public good, so 
people may free ride. Finally, grass-roots monitoring currently favoured by development community. In the 2004 World Development Report shows the important of development community: "Putting poor people at the centre of service provision: enabling them to monitor and discipline service providers, amplifying their voice in policymaking, and strengthening the incentives for service providers to serve the poor." This means that society or community participation on monitoring corruption would be an effective way for eradicating corruption.

\section{E. CONCLUDING REMARKS}

In conclusion, the relationship between decentralisation and corruption are complex and cannot be summarized by simple, unconditional statements. In one side, decentralisation is expected to have moderating impact on corruption, by increasing the role of the local government and accentuating the forces of inter-jurisdictional and political competition. On the other side, decentralisation has a positive impact on corruption, raising individual propensity to accept bribes due to an increasing an opportunities for corruption at local level.

Evidence from some study on decentralisation and corruption in Indonesia shows that some people in survey believed that corruption in decentralisation era is worse than before the implementation of decentralisation. In addition, a year after regional autonomy entered into force in 2001, a wave of corruption cases swept across Indonesia's newly empowered regional parliaments. Thus, many member of regional parliament was involved in corruption. In order to combating corruption both at national and local level, government has initiatives for addressing this problem with several approaches (top-down monitoring, bottom-up monitoring, and grass root monitoring).

\section{REFERENCES}

Bardhan P and Mookherjee D, 2000, Capture and governance at local and national levels, American Economic Review, Vol. 90 (2), pp. 135-139.

Carbonera E, 2000, Corruption and decentralisation, Working Paper 342/83, Dipartimento di Scienze Economiche, Università di Bologna.

Davidsen S, Juwono V and Timberman D G, 2006, Curbing Corruption in Indonesia, 2004-2006: A Survey of National Policies and Approaches, Centre for Strategic and International Studies Indonesia.

Estache, A. and Sinha S, 1995, Does Decentralisation Increase Public Infrastructure Expenditure?, in A. Estache (ed) Decentralizing Infrastructure: Advantages and Limitations, World Bank Discussion Papers 290, Washington D.C.

Fisman, R. and Gatti R, 2002, Decentralisation and Corruption: Evidence across Countries, Journal of Public Economics, vol. 83, p. 325-345

Henderson J V and Kuncoro A, 2004, Corruption in Indonesia, NBER Working Paper.

Huther, J. and Shah A, 1998, Applying a Simple Measure of Good Governance to the Debate on Fiscal Decentralisation, World Bank Policy Research Working Paper, no.1894.

ICW (Indonesian Corruption Watch), 2006, Riset Korupsi di Indonesia, http://antikorupsi.org/ mod.php?mod=publisher\&op=viewarticle\&cid=28\&artid=7434, accessed on 10 January 2008.

Kuncoro A, 2005, Bribery in Indonesia: Evidence from Micro Data, Bulletin of Indonesian Economic Studies, December, 2005.

Kuncoro A, 2006, Decentralisation and Corruption in Indonesia: Manufacturing Firms Survival under Decentralisation, Working Paper Series Vol. 2006-25, The International Centre for the Study of East Asian Development, Kitakyushu.

Mauro P, 1995, Corruption and Growth, Quarterly Journal of Economics CX, No. 3 (August), pp. 681-712. 


\section{Journal of Indonesian Applied Economics}

Vol. 4 No. 1 Mei 2010, 34-42

Olken, 2005, Monitoring Corruption: Evidence from a Field Experiment in Indonesia, Presented at the When Institutions Are Weak: Strategies for Change pre-conference July 6, 2005 www.imf.org/external/np/res/seminars/2005/weak/bo.pdf, accessed on 7 January 2008

Prud'homme R, 1995, The dangers of Decentralisation, The World Bank Research Observer, Vol. 10 (2), pp. 201-220.

Rinaldi T, Purnomo M, and Damayanti D, 2007, Memerangi Korupsi di Indonesia yang Terdesentralisasi: Studi Kasus Penanganan Korupsi Pemerintahan Daerah, Justice for the Poor Project, World Bank.

Shleifer, A. and Vishny R W, 1993, Corruption, Quarterly Journal of Economics, vol. 108, p.599617.

Smoke P and Lewis B, 1996, Fiscal Decentralisation in Indonesia: A new approach to an old idea, World Development, Vol. 24, No. 8, pp. 1281-1299.

Tanzi V, 1994, Corruption, Governmental Activities and Markets, IMF Working Papers 94/99. Washington DC: International Monetary Fund.

Transparency international, 2008, Corruption Perceptions Index (CPI), http:// www.transparency.org/news_room/in_focus/2007/cpi2007/cpi_2007 table, accessed on 10 January 2008

Treisman D, 2000, The Causes of Corruption: A Cross-National Study, Journal of Public Economic, vol. 76, p. 300-457.

World Bank, 2003, Combating Corruption in Indonesia: Enhancing Accountability for Development, East Asia Poverty Reduction and Economic Management Unit, www.siteresources.worldbank.org/.../Publication/03-Publication/ Combating+Corruption+in+Indonesia-Oct15.pdf, accessed on 10 January 2008

World Development Report 2004: Making Services Work For Poor People, the World Bank and Oxford University Press. http://econ.worldbank.org/WBSITE/EXTERNAL/EXTMODELSITE/

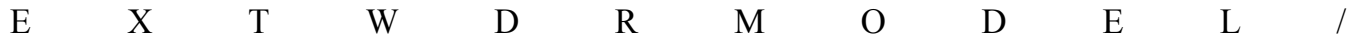
0,ImgPagePK:64202988-entityID:000090341_20031007150121 pagePK:64217930-piPK:64217936-theSitePK:477688,00html accessed on 11 January 2008 